\title{
Comparison of obstetric outcomes of pregnancies after donor oocyte IVF: Three-arm age-matched retrospective cohort study
}

\author{
Vikas Yadav, Priyanka Bakolia, Neena Malhotra*, Reeta Mahey, Neeta Singh, Alka Kriplani
}

Department of Obstetrics and Gynecology, AIIMS, Delhi, India

Received: 17 November 2017

Accepted: 18 December 2017

*Correspondence:

Dr. Neena Malhotra,

E-mail: malhotraneena@yahoo.com

Copyright: (C) the author(s), publisher and licensee Medip Academy. This is an open-access article distributed under the terms of the Creative Commons Attribution Non-Commercial License, which permits unrestricted non-commercial use, distribution, and reproduction in any medium, provided the original work is properly cited.

\begin{abstract}
Background: Oocyte donation has become widely used as a treatment option for infertile couples. The few available studies report conflicting evidence about the risk of hypertensive disorders in donor oocyte pregnancies after adjusting for maternal age and it is unclear whether pregnancy complications and obstetric risks are due to oocyte donation or to confounding factors such as maternal age. The aim of the present study was to evaluate and compare obstetric complications between women who conceived after oocyte donation and age-matched control women with spontaneous conception and self oocyte IVF conception.

Methods: The present study comprised of women aged 20-45 years conceived from oocyte donation $(n=104)$ between $1^{\text {st }}$ December 2010 to $15^{\text {th }}$ October 2017. Two age-matched control groups-Self oocyte IVF $(n=150)$ and the other containing women who conceived spontaneously $(n=312)$ were used for comparison of obstetric and perinatal outcomes.

Results: Mean maternal age was statistically significantly higher in the Donor oocyte IVF group as compared to self oocyte ivf and spontaneous conception group. Miscarriage, first trimester bleeding, pregnancy induced hypertension and gestational diabetes mellitus was significantly higher in Donor oocyte IVF group as compared to self-oocyte and spontaneous conception group $(\mathrm{p}=0.001)$. Using multiple logistic regression analysis age class adjusted PIH and GDM incidence was significantly higher in donor oocyte group as compared to spontaneous conception $(\mathrm{P}=0.010)$. There was significant variation in perinatal outcomes between the three groups.

Conclusions: Oocyte donation should be treated as an independent risk factor for miscarriage, first trimester bleeding, hypertensive disorder and gestational diabetes mellitus in pregnancy.
\end{abstract}

Keywords: First trimester bleeding, Gestational diabetes mellitus, Oocyte donation, Pregnancy induced hypertension

\section{INTRODUCTION}

Oocyte donation is a well-established method for the treatment of infertility in women. ${ }^{1}$ Oocyte donation was introduced in 1984, since than it has allowed women with ovarian insufficiency to become pregnant. ${ }^{2}$ As success rates following conventional IVF decline significantly after the age of 40 years, and viable pregnancies are infrequent beyond the age of 42 years. Oocyte donation permits dissociation of uterine and oocyte age. Oocyte donation is also offered to patients who repeatedly fail to conceive with standard IVF. ${ }^{3}$ Conception after oocyte donation is unique, because they have been achieved by an embryo which is immunologically different from the mother. This may be the cause of increased obstetrical and perinatal risk associated with these pregnancies.

Hypertensive disorders of pregnancy are one of the major causes of maternal morbidity and mortality leading to 10$15 \%$ of maternal deaths, especially in the developing world. ${ }^{4,5}$ The most common complication noted in pregnancies after donor oocyte IVF is pregnancy induced 
hypertension, ranging from 16 to $40 \%$ of women. ${ }^{6-9}$ Some researchers have proposed that it is not maternal age but the allogenic fetus that may predispose women to maternal hypertensive disorders, fetal growth restriction (FGR), abnormalities in placentation and gestational diabetes mellitus. ${ }^{10-15}$ Considering these conflicts on the results of pregnancy and neonatal outcome we planned to analyze our data in this regards so as to enable us counsel our women likewise.

In India, with increasing availability and accessibility certainly more couples are availing the benefits of assisted reproductive techniques using oocyte donation for above conditions. In a retrospective comparative cohort study, we aimed to evaluate and compare multiple obstetric and perinatal outcomes including abortion, preterm labor, antepartum hemorrhage, intra hepatic cholestasis pregnancy (ICP), gestational diabetes mellitus, pre-eclampsia, fetal growth restriction, fetal birth weight and compare these variables between donor oocyte conception group, self oocyte IVF group and spontaneous conception group. The outcome of this study provides important information for women considering using donor oocytes as a treatment for infertility.

\section{METHODS}

The present study was a retrospective comparative cohort study comprised of all women between the age of 20-45 years who conceived from oocyte donation $(n=104)$ between $1 / 12 / 2010$ to $15 / 10 / 2017$. The period was chosen in view of the modifications in regulations of third party reproduction which were implemented by the Indian Council of Medical Research (ICMR), and were implemented from 2010. ${ }^{16}$ Obstetric and perinatal outcomes were compared with all women who had conceived with self-oocyte $(n=150)$, and all women who had spontaneous conception $(n=312)$. Spontaneous conception patients were selected in the same time period in a ratio of 1:3.Patients were recruited retrospectively from hospital data who were booked at first antenatal visit between 6-9 weeks with no previous known medical or surgical comorbidity .Obstetric and perinatal outcome of these patients were also retrieved from hospital data base during the same period at the Center for Assisted Reproduction Techniques (ART) of Institute, with all babies followed in the neonatal division.

The ICMR prohibits the use of oocytes donated by a relative or a known friend of either the wife or the husband. Considering the proposed allogenic theory which was suggested to be a reason for adverse perinatal outcome we excluded women who underwent IVF with donor oocytes using siblings as donors prior to this period. All oocyte donors selected were in the age group of 21-30 years with mean age of $25 \pm 4.42$ years with atleast one living issue from previous conception.

The process involved controlled ovarian stimulation and retrieval of the donor oocytes, preparation of recipient endometrium and pregnancy management. All donors were stimulated by antagonist protocol. Ovarian stimulation was done with gonadotrophins starting from day-2 or 3 of menstruation, with recombinant FSH (Injection Gonal-F, Merck Serono Specialties Pvt Ltd., Italy Gonal F, Merck Serono Mumbai Ltd, India) in dosages depending on the donor's age, BMI, ovarian reserves including AMH levels and antral follicle counts assessed prior to the start of cycle. GnRH antagonist (cetrorelix $0.25 \mathrm{mg} /$ day, Cetrotide, Merck Serono Specialties Pvt Ltd., Italy Gonal F, Merck Serono Mumbai Ltd India) was started from sixth day of stimulation. Ovulation trigger was given when $\geq 3$ follicles reached a diameter of $18 \mathrm{~mm}$ with recombinant hCG (Injection ovitrelle, 250 micrograms, Merck Serono Mumbai Ltd, India). Oocyte retrieval was done after 34$36 \mathrm{hrs}$ transvaginally under ultrasound guidance. The retrieved oocytes were inseminated or injected with the male partner's sperms. The resultant embryos formed were frozen or transferred to the recipient if her endometrial lining was deemed prepared after estrogen priming (Endometrial thickness of $\geq 8 \mathrm{~mm}$ ).

\section{Endometrial preparation of recipients}

Oocyte recipients underwent down regulation with GnRH agonist (Injection Lupride, Bayer Zydus Pharma Ltd., Mumbai) $0.5 \mathrm{mg}$ subcutaneous daily from mid luteal phase (day 21) of the preceding menstrual cycle. Endometrium was prepared with estradiol valerate $4 \mathrm{mg}$ daily from day 1 of bleeding increased to $6 \mathrm{mg}$ per from day 8 of the cycle until the endometrium reached a thickness of $\geq 8 \mathrm{~mm}$. Progesterone (Injection susten 100 mg im, SUN Pharmaceutical Mumbai, India) was started on the day of oocyte retrieval of donor and continued until 14 days after embryo transfer. Embryo transfers were done on day 3 or day 5 depending on the embryo grading and the recipients' endometrial preparation. In cases where the endometrium did not agree despite hormone preparation the embryo was frozen and subsequently transferred in frozen embryo transfer (FET) cycle. The progesterone replacement was done in the form of micronized progesterone (Injection susten 100 mg im, SUN Pharmaceutical Mumbai, India)

\section{Pregnancy follow up}

Pregnancy was defined by rising beta-hCG levels done after 16 days of the embryo transfer and was further confirmed by ultrasonographic visualization of gestational sac at 6 weeks. Estrogen was tapered and stopped once fetal heart activity was documented and progesterone support continued until 10-12 weeks of gestation. During pregnancy both groups were followed up in antenatal clinic of our institute.

The obstetrical parameters compared in both groups included outcomes as, first trimester bleeding, miscarriage, pre-eclampsia, oligoamnios, gestational diabetes mellitus, Antepartum hemorrhage, preterm 
delivery, fetal growth restriction (FGR), Intrahepatic cholestasis (ICP), mode of delivery and post-partum complications. The neonatal outcomes birth weights, Apgar scores, NICU stay, congenital anomaly were compared in three groups.

Miscarriage: Bleeding, expulsion of fetus or disappearance of cardiac activity in utero before 20 weeks gestation.

Preeclampsia: Blood pressure $\geq 140 / 90 \mathrm{mmHg}$ with proteinuria after 20 weeks gestation

Gestational diabetes mellitus: Carbohydrate intolerance first recognized during pregnancy

Preterm delivery: Delivery before 37 weeks gestation

FGR: Birth weight less than $10^{\text {th }}$ percentile for the gestation age

Fetal outcome such as mean birth weight, APGAR score $<8$, still birth rate, Small for date/Large for date fetus and early neonatal complication such as hyperbilirubinemia, respiratory distress, hypoglycemia and congenital anomaly were also compared. Age matched subgroup analysis was done using logistic regression analysis to compare the incidence of pregnancy induced hypertension and gestational diabetes mellitus between donor oocyte, self oocyte and spontaneous conception group

\section{Statistical analysis}

Data was presented in numbers and percentages. Statistical analysis was performed with chi-square test for categorical variables. We compared the mean via t-test. Continuous outcomes (estimated gestation age, birth weight) were compared using t-test and linear regression; dichotomous outcomes were analyzed by logistic regression. Further analysis was performed, if indicated, to control for confounding variables using multivariable linear and logistic regression analysis. $\mathrm{P}<0.05$ was considered statistical significant. Odds ratios (ORs) and 95\% CIs were established as well as multiple logistic regression.

\section{RESULTS}

During the study period $1 / 12 / 2010$ to $15 / 10 / 2017,104$ women with donor oocyte conception were compared with 150 self oocyte IVF conception and 312 spontaneous conception women during the same period. Mean maternal age was statistically significantly higher in the Donor oocyte IVF group as compared to spontaneous conception group. Parity between the groups were comparable. There were a higher number of women in the advanced age ( $>35$ years) in the donor group.

Table 1: Demographic profile of the study group-Donor oocytes recipients and control group-Self oocyte conception.

\begin{tabular}{|c|c|c|c|c|}
\hline Outcome & $\begin{array}{l}\text { Group } 1 \text { Donor IVF } \\
\text { No. }(\%), \mathbf{N}=104\end{array}$ & $\begin{array}{l}\text { Group } 2 \text { Self IVF } \\
\text { No. }(\%), \mathbf{N}=150\end{array}$ & $\begin{array}{l}\text { Group } 3 \\
\text { Low risk patient } \\
\text { No. }(\%), \mathbf{N}=312\end{array}$ & $\begin{array}{l}P \text { value and } \\
\text { significance }\end{array}$ \\
\hline Mean age (years) & $34.48 \pm 5.3$ & $31 \pm 3.97$ & $31.74 \pm 4.43$ & $\begin{array}{l}\mathrm{P}=0.001 \text { (overall) } \\
1 \text { vs } 2=\mathrm{p}=0.001 \\
3 \text { vs } 2=\mathrm{p}=0.290 \\
3 \text { vs } 1=\mathrm{p}=0.001\end{array}$ \\
\hline \multicolumn{5}{|l|}{ Age distribution } \\
\hline$\leq 30$ & $26(25.0)$ & $62(41.4)$ & $194(62.2)$ & \multirow{3}{*}{$\mathrm{P}=0.001$ (overall) } \\
\hline $31-40$ & $63(60.6)$ & $47(31.3)$ & $89(28.5)$ & \\
\hline$\geq 41$ & $15(14.4)$ & $41(27.3)$ & $29(9.3)$ & \\
\hline \multicolumn{5}{|l|}{ Obstetric history } \\
\hline Primigravida & $74(71.21)$ & $121(80.6)$ & $232(74.36)$ & \multirow{3}{*}{$\mathrm{P}=0.179(\mathrm{NS})$} \\
\hline Multigravida & $30(28.9)$ & $29(19.33)$ & $80(25.64)$ & \\
\hline Previous abortions & $16(15.38)$ & $21(14)$ & $54(17.3)$ & \\
\hline
\end{tabular}

Obstetric events: miscarriage, first trimester bleeding, pregnancy induced hypertension and GDM has significantly higher incidence in donor oocyte IVF group as compared to self oocyte IVF group and spontaneous conception group. There was statistically higher incidence of oligoamnios, antepartum hemorrhage, preterm delivery, intrahepatic cholestasis (ICP), fetal growth restriction (FGR), Post partum hemorrhage and mode of delivery among donor oocyte IVF group as compared to spontaneous conception group $(\mathrm{P}=0.001)$. 
Table 2: Comparison of obstetrics outcome of all pregnancies of donor oocyte recipients with self oocyte conception.

\begin{tabular}{|c|c|c|c|c|}
\hline Outcome & $\begin{array}{l}\text { Group } 1 \\
\text { Donor IVF } \\
\text { No. }(\%) \\
\text { N=104 }\end{array}$ & $\begin{array}{l}\text { Group } 2 \\
\text { Self IVF } \\
\text { No. }(\%) \\
\mathbf{N}=150\end{array}$ & $\begin{array}{l}\text { Group } 3 \\
\text { Low risk } \\
\text { patients } \\
\text { No. }(\%), \mathbf{N}=\mathbf{3 1 2}\end{array}$ & $P$ value and significance \\
\hline \multicolumn{5}{|l|}{ Obstetric events } \\
\hline Early Onset OHSS* & $1(0.9)$ & $2(1.3)$ & 0 & $\mathrm{P}>0.05(\mathrm{NS})$ \\
\hline First trimester bleeding & $21(20.2)$ & $10(6.66)$ & $14(4.5)$ & $\begin{array}{l}\mathrm{P}=0.001 ; 1 \text { vs } 2: \mathrm{P}=0.001(\mathrm{Sig}) \\
2 \text { vs } 3: \mathrm{P}=0.323(\mathrm{NS}) \\
1 \text { vs } 3: \mathrm{P}=0.001(\mathrm{Sig})\end{array}$ \\
\hline Miscarriage & $29(27.9)$ & $14(9.33)$ & $19(6.09)$ & $\begin{array}{l}\mathrm{P}=0.001(\mathrm{Sig}) ; 1 \text { vs } 2: \mathrm{P}=0.001(\mathrm{Sig}) \\
2 \text { vs } 3: \mathrm{P}=0.323(\mathrm{NS}) \\
1 \text { vs } 3: \mathrm{P}=0.001(\mathrm{Sig})\end{array}$ \\
\hline Pre-eclampsia* & $35(33.7)$ & $11(7.3)$ & $23(7.4)$ & $\begin{array}{l}\mathrm{P}=0.001(\mathrm{Sig}) ; 1 \text { vs } 2: \mathrm{P}=0.001(\mathrm{Sig}) \\
2 \text { vs } 3: \mathrm{P}=0.323(\mathrm{NS}) \\
1 \text { vs } 3: \mathrm{P}=0.001(\mathrm{Sig})\end{array}$ \\
\hline GDM* & $36(34.6)$ & $16(10.67)$ & $25(8.01)$ & $\begin{array}{l}\mathrm{P}=0.001 ; 1 \text { vs } 2: \mathrm{P}=0.001(\mathrm{Sig}) \\
2 \text { vs } 3: \mathrm{P}=0.347(\mathrm{NS}) \\
1 \text { vs } 3: \mathrm{P}=0.001(\mathrm{Sig})\end{array}$ \\
\hline $\mathrm{APH}^{*}$ & $13(12.5)$ & $6(4)$ & $8(2.56)$ & $\begin{array}{l}\mathrm{P}=0.001 ; 1 \text { vs } 2: \mathrm{P}=0.011(\mathrm{Sig}) \\
2 \text { vs } 3: \mathrm{P}=0.399(\mathrm{NS}) \\
1 \text { vs } 3: \mathrm{P}=0.001(\mathrm{Sig})\end{array}$ \\
\hline Preterm delivery* & $57(54.81)$ & $34(22.67)$ & $9(2.88)$ & $\begin{array}{l}\mathrm{P}=0.001 ; 1 \mathrm{vs} 2: \mathrm{P}=0.001(\mathrm{Sig}) \\
\text { 2vs } 3: \mathrm{P}=0.947(\mathrm{NS}) \\
1 \text { vs } 3: \mathrm{P}=0.001(\mathrm{Sig})\end{array}$ \\
\hline Abnormal presentation* & $5(4.8)$ & $9(6)$ & $8(2.56)$ & $\mathrm{P}=0.175(\mathrm{NS})$ \\
\hline $\begin{array}{l}\text { Post partum } \\
\text { complication* }\end{array}$ & $7(6.73)$ & $3(2)$ & $4(1.28)$ & $\begin{array}{l}\mathrm{P}=0.012(\mathrm{Sig}) ; 1 \text { vs } 2: \mathrm{P}=0.057(\mathrm{NS}) \\
2 \text { vs } 3: \mathrm{P}=0.554(\mathrm{NS}) \\
1 \text { vs } 3: \mathrm{P}=0.003(\mathrm{Sig})\end{array}$ \\
\hline \multicolumn{5}{|l|}{ Mode of delivery } \\
\hline Vaginal & $9(8.7)$ & $16(10.7)$ & $212(67.95)$ & \multirow{6}{*}{$\begin{array}{l}\mathrm{P}=0.001(\mathrm{Sig}) ; 1 \text { vs } 2: \mathrm{P}=0.596(\mathrm{NS}) \\
2 \text { vs } 3: \mathrm{P}=0.001(\mathrm{Sig}) \\
1 \text { vs } 3: \mathrm{P}=0.001(\mathrm{Sig})\end{array}$} \\
\hline Spontaneous & 9 & 13 & 171 & \\
\hline Induced & 0 & 3 & 41 & \\
\hline LSCS & 95 & 134 & 100 & \\
\hline Elective* & 32 & 96 & 83 & \\
\hline Emergency* & 63 & 48 & 17 & \\
\hline
\end{tabular}

GDM: Gestational diabetes mellitus; OHSS : Ovarian hyperstimulation syndrome, APH: Antepartum hemorrhage; FGR :Fetal growth restriction, ICP: Intrahepatic cholestasis of pregnancy, *Total Donor pregnancy=56, *Total Self oocyte pregnancy=100

Table 3: Age adjusted odd's ratio for PIH.

\begin{tabular}{|llll|}
\hline Variable & $\begin{array}{l}\text { Adjusted } \\
\text { odd's ratio }\end{array}$ & P value & $95 \%$ CI \\
\hline Control (Ref.) & 1.0 & 0.917 & $0.49-2.20$ \\
\hline Self & 1.04 & 0.001 & $2.64-8.81$ \\
\hline Donor & 4.8 & & \\
\hline
\end{tabular}

There was no statistical difference in the incidence of early onset OHSS, anemia, oligoamnios, antepartum hemorrhage, preterm delivery, intrahepatic cholestasis (ICP), fetal growth restriction (FGR), abnormal presentation, mode of delivery and postpartum hemorrhage between donor oocyte IVF and self oocyte IVF group ( $>0.05 \mathrm{NS})$. Using multiple logistic regression analysis age class adjusted PIH and GDM incidence was significantly higher in donor oocyte group as compared to spontaneous conception group $(\mathrm{P}=0.010)$, even after removing age as a confounder as shown in Table 3 and Table 4.

Table 4: Age adjusted odd's ratio for GDM.

\begin{tabular}{|llll} 
Variable & $\begin{array}{l}\text { Adjusted } \\
\text { odd's ratio }\end{array}$ & $\begin{array}{l}\text { P } \\
\text { value }\end{array}$ & $95 \%$ CI \\
\hline Control (Ref.) & 1.0 & 0.257 & $0.76-2.87$ \\
\hline Self & 1.47 & 0.001 & $2.50-8.15$ \\
\hline Donor & 4.51 & & \\
\hline
\end{tabular}

Perinatal outcome (Table 5) including mean birth weight, APGAR score, incidence of SFD, hyperbilirubinemia and respiratory distress was significantly higher in donor oocyte group as compared to spontaneous conception group $(\mathrm{p}=0.001)$ but outcomes including mean birth 
weight, APGAR score, respiratory distress, congenital anomaly did not suggest any significant variation between the donor and self-oocyte IVF cycles $(\mathrm{P}>0.05)$.

Table 5: Comparison of perinatal outcome of all pregnancies of donor oocyte recipient with self oocyte IVF.

\begin{tabular}{|c|c|c|c|c|}
\hline Outcome & $\begin{array}{l}\text { Group } 1 \\
\text { Donor IVF } \\
\text { ( } \mathrm{n}=104) \text { No. }(\%) \\
\mathrm{N}=123 \text { fetuses }\end{array}$ & $\begin{array}{l}\text { Group } 2 \\
\text { Self IVF }(\mathrm{n}=\mathbf{1 5 0}) \\
\text { No. }(\%) \\
\mathbf{N}=\mathbf{1 8 0} \text { fetuses }\end{array}$ & $\begin{array}{l}\text { Group } 3 \\
\text { Low risk patients } \\
(\mathrm{n}=312) \text { No. }(\%) \\
\mathbf{N}=\mathbf{3 1 9} \text { fetuses }\end{array}$ & $P$ value and significance \\
\hline \multicolumn{5}{|l|}{ Fetal outcome } \\
\hline Mean birth weight & $2489.78 \pm 652.30$ & $2442.06 \pm 712.03$ & $2764.07 \pm 602.70$ & $\begin{array}{l}\mathrm{P}=0.001 ; 1 \mathrm{vs} 2: \mathrm{P}>0.05(\mathrm{NS}) \\
\text { 2vs3: } \mathrm{P}=0.001(\mathrm{Sig}) \\
\text { 1vs3: } \mathrm{P}=0.001(\mathrm{Sig})\end{array}$ \\
\hline Twins & $19(15.45)$ & 30 (16.67) & 7 (2.19) & $\begin{array}{l}\mathrm{P}=0.001 ; 1 \text { vs } 2: \mathrm{P}=0.77(\mathrm{NS}) \\
2 \text { vs } 3: \mathrm{P}=0.001(\mathrm{Sig}) \\
1 \text { vs } 3: \mathrm{P}=0.001(\mathrm{Sig})\end{array}$ \\
\hline Apgar $<8$ & $27(21.95)$ & $26(14.44)$ & $9(2.82)$ & $\begin{array}{l}\mathrm{P}=0.001 ; 1 \mathrm{vs} 2: \mathrm{P}=0.091(\mathrm{NS}) \\
\text { 2vs3: } \mathrm{P}=0.001(\mathrm{Sig}) \\
\text { 1vs3: } \mathrm{P}=0.001(\mathrm{Sig})\end{array}$ \\
\hline SFD & $31(25.20)$ & $22(12.22)$ & $21(6.58)$ & $\begin{array}{l}\mathrm{P}=0.001 ; 1 \mathrm{vs} 2: \mathrm{P}=0.003 \text { (Sig) } \\
\text { 2vs3: } \mathrm{P}=0.031 \text { (Sig) } \\
\text { 1vs3: } \mathrm{P}=0.001 \text { (Sig) }\end{array}$ \\
\hline LFD & $5(4.07)$ & $6(3.33)$ & $5(1.57)$ & $\mathrm{P}=0.247(\mathrm{NS})$ \\
\hline Hyperbilirubinemia & $17(13.82)$ & $7(3.89)$ & $6(1.88)$ & $\begin{array}{l}\mathrm{P}=0.001 ; 1 \mathrm{vs} 2: \mathrm{P}=0.002 \text { (Sig) } \\
\text { 2vs3: } \mathrm{P}=0.176(\mathrm{NS}) \\
\text { 1vs3: } \mathrm{P}=0.001(\mathrm{Sig})\end{array}$ \\
\hline Respiratory distress & $29(23.58)$ & $23(12.78)$ & $7(2.19)$ & $\begin{array}{l}\mathrm{P}=0.001 ; 1 \mathrm{vs} 2: \mathrm{P}=0.014 \text { (Sig) } \\
\text { 2vs3: } \mathrm{P}=0.001 \text { (Sig) } \\
\text { 1vs3: } \mathrm{P}=0.001 \text { (Sig) }\end{array}$ \\
\hline Hypoglycemia & $4(3.25)$ & $5(2.78)$ & $4(1.25)$ & $\mathrm{P}=0.314(\mathrm{NS})$ \\
\hline Still birth & $2(1.63)$ & $2(1.11)$ & $3(0.94)$ & $\mathrm{P}=0.879(\mathrm{NS})$ \\
\hline Congenital anomaly & $2(1.63)$ & $3(1.67)$ & $4(1.25)$ & $0.91(\mathrm{NS})$ \\
\hline
\end{tabular}

SFD: Small for date baby: LFD: Large for date

\section{DISCUSSION}

Donor oocyte (DO) IVF provides the opportunity of pregnancy for many women, but at the same time increases the risks associated with pregnancy. Multiple gestations, advanced age, and underlying polycystic ovary syndrome are constant confounding factors for all studies examining the association between assisted reproductive techniques (ARTs) and hypertensive disorders in pregnancy. ${ }^{17}$ Thomopoulos showed that ART pregnancies, especially IVF techniques, are accompanied by increased risks for gestational hypertension as compared with non-ART

pregnancies, even after adjustment for confounding factors. ${ }^{17}$ The success of pregnancy depends upon an appropriate implantation and placental function. ${ }^{18}$ The risk of hypertensive disorders of pregnancy in DO pregnancies can be explained on the basis of an immunological mechanism. ${ }^{19,20}$ In DO pregnancies the fetus is allogeneic to the gestational carrier. Therefore, the mother has to cope with a higher degree of antigenic dissimilarity compared with spontaneously conceived pregnancies. ${ }^{21,22}$ Increased immunological activity and fibrinoid deposition was noted at the maternal-fetal interface in DO pregnancies.

The design with three control groups allows us to compare outcomes not only with self oocyte conceptions but also with the background Spontaneous conception population. This is one of the largest studies on perinatal outcomes in children conceived after donor oocyte IVF Wang et al. ${ }^{23}$ studied 616 nulliparous and 2,213 multiparous Norwegian women with a mean age of 37 years, and they found no increased risk of preeclampsia, PTB, or LBW compared with younger women.

The present study showed an increased risk of GDM and $\mathrm{PIH}$ among women with donor oocyte pregnancies as compared with self oocyte IVF conception and spontaneous conception group. When logistic regression analysis was done for age-class matching, there still existed significantly higher incidence of PIH in donor oocyte pregnancies as compared to self oocyte pregnancies. 
The strength of this study includes the homogeneity of the obstetric care and the ability to have an appropriate control group for the donor oocyte IVF study population. The close matching of the control group for infertility, parity, plurality, is a unique feature of this study and makes the result more compelling. The multiple logistic regression analysis also addresses well the maternal age.

On one hand assisted reproductive technology using oocyte donation has enabled women at advanced age or with ovarian failure to achieve pregnancy while on the other hand conception after oocyte donation can subject them to a higher risk of maternal morbidity and mortality and this should be part of counselling the couple while they set out to donor oocyte IVF cycle. ${ }^{24}$ Obstetrician and Pediatrician need to be aware of the increased pregnancy risks, which should be managed appropriately during the pregnancy, delivery and puerperium period. ${ }^{25}$

\section{CONCLUSION}

Donor oocyte IVF has proven to be an effective form of infertility treatment. Oocyte donation should be treated as an independent risk factor for Miscarriage, hypertensive disorder, antepartum hemorrhage, preterm delivery and Gestational diabetes mellitus in pregnancy. Women should be informed of the risks and Donor oocyte pregnancies should be managed in high risk obstetric clinics. Our study provides useful information for counseling couples who are considering the use of donor oocyte to achieve pregnancy.

\section{Funding: No funding sources}

Conflict of interest: None declared

Ethical approval: The study was approved by the Institutional Ethics Committee

\section{REFERENCES}

1. Ferraretti AP, Goossens V, Kupka M, Bhattacharya S, de Mouzon J, Castilla JA, et al. Assisted reproductive technology in Europe, 2009: results generated from European registers by ESHRE. Hum Reprod 2013;28(9):2318-31.

2. Lutjen P, Trounson A, Leeton J. The establishment and maintenance of pregnancy using in vitro fertilization and embryo donation in a patient with primary ovarian failure. Nature. 1984;307(5974):174-5.

3. Rosenwaks Z. Donor eggs:their application in modern reproductive technologies. Fertil Steril. 1987;47:895-909.

4. Devroey P, Wisanto A, Camus M. Oocyte donation in patients without ovarian function. Hum Reprod. 1988;3:699-704.

5. Wagner SJ, Barac S, Garovic VD. Hypertensive pregnancy disorders: current concepts. J Clin Hypertens (Greenwich). 2007;9:560-66.

6. Serhal PF, Craft IL. Oocyte donation in 61 patients. Lancet. 1989;1:1185-7.
7. Blanchette H. Obstetric performance of patients after oocyte donation. Am J Obstet Gynecol. 1993;168:1803-7.

8. Abdalla HI, Billett A, Kan AK, Baig S, Wren M, Korea L, et al. Obstetric outcome in 232 ovum donation pregnancies. $\mathrm{Br} \quad \mathrm{J}$ Obstet Gynaecol 1998;105(6 Pt 1):332-7.

9. Soderstrom-Anttila V, Foudila T, Hovatta O. A randomized comparative study of highly purified follicle stimulating hormone and human menopausal gonadotrophin for ovarian hyperstimulation in an oocyte donation programme. Hum Reprod. 1996;11:1864-70.

10. Klatsky PC, Delaney SS, Caughey AB, Tran ND, Schattman GL, Rosenwaks Z. The role of embryonic origin in preeclampsia: a comparison of autologous in vitro fertilization and ovum donor pregnancies. Obstet Gynecol. 2010;116(6):1387-92.

11. Levron Y, Dviri M, Segol I, Yerushalmi GM, Hourvitz A, Orvieto R, et al. The 'immunologic theory' of preeclampsia revisited: a lesson from donor oocyte gestations. Am J Obstet Gynecol. 2014;211(4):383.e1-5.

12. Salha O, Sharma V, Dada T, Nugent D, Rutherford AJ, Philips $S$ et al. The influence of donated gametes on the incidence of hypertensive disorders of pregnancy. Hum Reprod. 1999;14:2268-73.

13. Sheffer-Mimouni G, Mashiach S, Dor J, Levran D, Seidman DS. Factors influencing the obstetric and perinatal outcome after oocyte donation. Hum Reprod. 2002; 17:2636-40.

14. Toner JP, Grainger DA, Frazier LM. Clinical outcomes among recipients of donated eggs: an analysis of the U.S. national experience, 1996-1998. Fertil Steril. 2002;78:1038-45.

15. Wiggins DA, Main E. Outcomes of pregnancies achieved by donor egg in vitro fertilization-a comparison with standard in vitro fertilization pregnancies. Am J Obstet Gynecol. 2005;192:20026.

16. The Assisted Reproductive Technologies (Regulation) Rules - 2010, Ministry of health and family welfare govt. of india, New delhi; Available at

http://www.icmr.nic.in/guide/ART\%20REGULATI ON\%20Draft\%20Rules\%201.pdf

17. Thomopoulos C, Tsioufis C, Michalopoulou H, Makris T, Papademetriou V, Stefanadis C. Assisted reproductive technology and pregnancy-related hypertensive complications: a systematic review. J Hum Hypertens. 2013;27:148-57.

18. Laresgoiti-Servitje E, Gomez-Lopez N, Olson DM. An immunological insight into the origins of preeclampsia. Hum Reprod Update. 2010;16:510-24.

19. LaMarca B, Cornelius D, Wallace K. Elucidating immune mechanisms causing hypertension during pregnancy. Physiology (Bethesda, Md). 2013;28:225-33.

20. Taglauer ES, Gundogan F, Johnson KL, Scherjon SA, Bianchi DW. Chorionic plate expression patterns 
of the maspin tumor suppressor protein in preeclamptic and egg donor placentas. Placenta. 2013;34:385-7.

21. Van MLPH, Scherjon SA, Claas FHJ. Egg donation pregnancy as an immunological model for solid organ transplantation. Transpl Immunol. 2011;25:8995.

22. van der Hoorn ML, Scherjon SA, Claas FH. Egg donation pregnancy as an immunological model for solid organ transplantation. Transpl Immunol. 2011;25:89-95.

23. Wang Y, Tanbo T, _Abyholm T, Henriksen T. The impact of advanced maternal age and parity on obstetric and perinatal outcomes in singleton gestations. Arch Gynecol Obstet. 2011;284:31-7.

24. Karnis MF, Zimon AE, Lalwani SI, Timmreck LS, Klipstein S, Reindollar RH. Risk of death in pregnancy achieved through oocyte donation in patients with Turner syndrome: a national survey. Fertil Steril. 2003;80(3):498-501.

25. Braat DD, Schutte JM, Bernardus RE, Mooij TM, van Leeuwen FE. Maternal death related to IVF in the Netherlands 1984-2008. Hum Reprod. 2010;25(7):1782-6.

Cite this article as: Yadav V, Bakolia $\mathrm{P}$, Malhotra N, Mahey R, Singh N, Kriplani A. Comparison of obstetric outcomes of pregnancies after donor oocyte IVF: Three-arm age-matched retrospective cohort study. Int J Reprod Contracept Obstet Gynecol 2018;7:529-35. 